\title{
MULTISCALE APPROACH OF THE EQUIVALENT THERMAL CONDUCTIVITY OF MODIFIED FOAM-FILLED AND NON-FILLED HOLLOW BRICK AND A BRICK WALL
}

\author{
Atheer Saad Hashim¹, Mushtaq F. Almensoury², Farooq Hassan Ali ${ }^{3}$, Hameed Kadhem \\ Hamzah $^{3}$, Mohammad Ghalambaz ${ }^{*}, 5$
}

\begin{abstract}
The energy loss through building components resulting in higher energy consumption, thus energy saving has become an essential aspect in design and comfort. This study aims to optimize the thermal insulation of red clay bricks used in the walls of buildings by using a multiscale method. The finite element approach in ABAQUS software has been used to simulate the bricks under different configurations and conditions. Due to cost and time challenges and difficulties in simulation and complex calculations, simplified and applicable equations have been derived to calculate thermal insulation properties. The results show that the paper's brick design has a significant thermal conductivity reduction that could reach more than one-third of the other corresponding studies. The study goes to fill the hollow bricks by the insulation polyurethane foam (PUF) and comparing the results with air hollow bricks. Besides its other advantages, the outcomes reveal that using the PUF has a noticeable desired-influence in thermal insulation when considering the heat transfer by convection and radiation inside the air cavity of bricks.
\end{abstract}

\section{Keywords: Hollow Clay Brick, PUF Foam, Multiscale Method, FEM, Equivalent Thermal Properties}

\section{INTRODUCTION}

The energy leak through building parts leads to higher energy consumption as a result of energy compensation. Energy-saving is a significant factor that has to be taken into account in building design and the level of indoor comfort. Nowadays, approximately half of the accounted social energy has been for buildings consumption $[1,2]$. Therefore, many procedures used to limit this issue and improve energy savings to the highest level [3]. One of the common methods to reduce energy consumption is to use insulations, especially in walls. There are many aspects of this approach; one of the popular approaches is using and insulation-layer integration into the building wall. Many studies have conducted to address the effects of various locations and angles of the insulation layer related to the foundation wall in order to optimize wall energy conversation[4].

Although this mechanism achieves suitable insulation performance [5,6], it raises the cost and duration of construction because of the adding of the insulation layer to the main wall [7]. Increasing the thermal resistance of the building walls without affecting the structural properties has been a fundamental aspect, and it should be taken into account through fundamental design steps [3]. Therefore, another technique, it is modifying the brick design by using of air cavities in the brick or block that reduce the weight and could increase the equivalent thermal resistance [8-10]. In bricks, the process of heat transfer in hollow brick can be represented by conduction, natural convection, and radiation in all domains, enclosures, between inner surfaces, [1,11]. The desired thermal performance with the addition of the cavities in bricks is based on the significant role of the natural convection heat transfer of the air inside the brick enclosures. There are detailed numerical and experimental studies $[2,12-$ 15] that tried to optimize the block or brick design with the purpose of enhancing the properties of thermal insulation. Sun and Fang[1] theoretically concluded that the brick cavities in non-aligned form have higher thermal resistance than the aligned form.

Many researchers focused on the conductivity reduction, and thus, they tried to increase the thermal resistance of the hollow concrete brick by changing the enclosures configuration [8,9,16-19] to gain an optimum equivalent heat transfer conditions for specific hollow brick designs. In addition, they concluded that the rectangle configuration of the enclosure exhibits the lowest thermal conductivity, especially when the fraction of void volume is dominated.

\footnotetext{
This paper was recommended for publication in revised form by Regional Editor N. Filiz Özdil

${ }^{1}$ Water Resources Engineering College, Al-Qasim Green University, IRAQ

${ }^{2}$ Mechanical Engineering Department, College of Engineering, University of Al-Qadisiyah, Diwaniyah, IRAQ

${ }^{3}$ Mechanical Engineering Department, College of Engineering, University of Babylon, IRAQ

${ }^{4}$ Department for Management of Science and Technology Development, Ton Duc Thang University, Ho Chi Minh City, Vietnam

${ }^{5}$ Faculty of Applied Sciences, Ton Duc Thang University, Ho Chi Minh City, Vietnam

*E-mail address: mohammad.ghalambaz@tdtu.edu.vn

Orcid id: 0000-0003-0142-5388, 0000-0002-2603-874X, 0000-0003-0082-3261, 0000-0003-0983-4776, 0000-0003-0965-2358

Manuscript Received 22 October 2019, Accepted 29 February 2020
} 
Al-Hadhrami and Ahmad [2] indicated that the hollow bricks with the size of 400 (length) x 200 (width) x 200 (height) mm, made from fired red clay, exhibited noticeable thermal-insulation properties compared to concrete bricks produced by using the guarded hot-plate technique. Alghamdi and Alharthi [10] used the same dimensions, and they agree with the above researchers concerning the required thermal properties of fired red clay. Antoniadis et al. [20] developed a new design with higher thermal insulation for the Greek hollow clay bricks by using the transient hot-wire technique.

Some studies have been carried out by filling the hollow brick cavities with insulating materials in order to eliminate the insider convection heat transfer. Al-Hazmy [21] and Jing Li et al.[19] proved that the insertion of a low thermal conductivity polymer foam in the form of full-cavity or bars can significantly reduce the heat transfer rate. Compared to the non-filled hollow brick, the heat transfer rate in the configuration of Al-Hazmy [21] and Jing $\mathrm{Li}$ et al.[19] was decreased to $36 \%$ and $45.78 \%$, respectively. Li et al.[19] demonstrated that filling the brick cavities by an insulation material, which has a thermal conductivity of $0.041(\mathrm{~W} / \mathrm{m}-\mathrm{K})$, exposed an obvious enhancement in thermal insulation performance. Bouchair [22] used the cork as an insulating material in small $(190 \times 145 \times 300 \mathrm{~mm})$ and big $(190 \times 100 \times 300 \mathrm{~mm})$ types of fired clay bricks. This author concluded that there are excellent improvements presented in both sizes as the highest were in the bigger size of bricks.

Al-Hadhrami and Ahmad [2], in an experimental study, investigated the thermal properties of nine types of red clay bricks and two types of concrete blocks. The researchers used an insulating mortar and filled the center hole with perlite, polystyrene, cement and/or mineral wool insulation. They demonstrated that there is a positive role of the insulating mortar in the thermal resistance of the wall, and proved the lower thermal conductivity filler exhibit the best thermal insulation brick. For their samples, they indicated that the maximum thermal resistance was in the lightweight clay brick and the smallest equivalent thermal conductivity gained with the mineral wool insulation filler and an insulating mortar, while the highest conductivity was with the perlite-cement mix filler and ordinary concrete mortar.

Alghamdi and Alharthi [10] proved that cavity regular shape and change in mortar thickness within the limits have not noticeably affected the equivalent thermal conductivity of the hollow brick or wall. Alghamdi and Alharthi used a multiscale three-dimensional (3D) finite-element to model the thermal conductivity of bricks and walls. They improve the insulation efficiency of the brick walls. The multiscale finite-element modeling is a simplified method of a brick wall by using unit cells as it introduces the structure by repeating itself throughout $X$, $\mathrm{Y}$, and $\mathrm{Z}$ spatial planes. Hollow bricks of the unit have been considered as a solid brick that carries the identical thermal properties gained from an individual model. This approach has avoided unnecessary computational time and cost compared to modeling a full 3D hollow-brick wall.

A recent design mechanism of enhancing thermal insulation is using a hollow block ventilated wall. It is based on heat exchange between air and block material by charging and discharging air through the block's hollow. This method can introduce significant thermal performance, especially when integrated with phase change material $[14,23]$. Furthermore, there are several works that have gone towards the use of nanomaterials in the field of improving thermal properties, for more details can be clearly shown in the studies [24-27].

This paper aims to thermally optimize a brick wall by using a multiscale method for a wall constructed from modified hollow clay bricks to obtain a low equivalent thermal conductivity. A low equivalent thermal conductivity can participate in saving energy by increasing the thermal resistance through the wall thickness. The effect of using insulation foams in the hollow brick cavities on the insulation performance of constructing walls will be addressed. This technique could be promising to promote the wall thermal-resistance and eliminate the need for using the integrated insulation layer.

Moreover, It should be noted that the thermal conductivity and resistance can be calculated by the standard heat transfer equations and methods such as experimental approaches, numerical simulations, finite-element (FE) /volume methods, etc. [1,11,17,28-32]. The major difficulties and challenges were the high cost and long time spent in the design, implementation, and simulation of heat transfer through the 3D brick and wall, especially during the optimization with several designs and dimensions of the bricks and walls. However, this study aims to reduce the computational cost and time of computing the thermal insulation properties by deriving simplified and applicable equations. This approach could reduce the use of complex calculation methods and could achieve readable outcomes. 


\section{MATERIAL AND MATHEMATICAL MODEL Insulation Polyurethane Foams}

Polymeric foams are one of the materials that consist of two phases a solid and a gas that are produced from varied kinds of polymers, e.g. polyethylene (PE), polyurethane (PU), polystyrene (PS), polyvinyl chloride (PVC) and so on, in the form of elastomeric, flexible, or rigid foams [7,33]. The popular polymeric foams in worldwide are the polyurethane foams (PUFs) followed by the polystyrene and polyvinyl chloride [33-36]. Closed-cells PUFs are commonly used in building constructions as an integrated insulation layer or as insulation filler in the wall cavities as they are considered the lower thermal conductivity that offers the best thermal resistance compared to the other insulation materials such as PS, PE, PVC, mineral wool and cellulose materials [37-42]. In the last two decades, studies focused on producing of PUFs from renewable feedstocks that increase the positive properties of the PUFs, especially when related to the environment [7,35]. With a temperature range of 469 to $403 \mathrm{~K}$, the rigid PUFs show significant thermal insulation properties [36,37,42,43]. The table below illustrates the thermal conductivity ranges of popular insulation materials.

Table 1. The thermal conductivity of common insulation materials

\begin{tabular}{|c|c|}
\hline Insulation materials & Thermal Conductivity (W/m-K) \\
\hline Polyurethane foams & $(0.02$ or even lower- 0.035$)[44]$ \\
\hline Mineral wool & $(0.037-0.055)[36]$ \\
\hline Expanded polystyrene & $(0.03-0.04)[22,36]$ \\
\hline Cellulose & $(0.04-0.065)[36]$ \\
\hline Cork & $(0.039-0.05)[22,36]$ \\
\hline
\end{tabular}

In addition to its significant thermal insulation, the composites of PUF are commonly prepared to enhance other properties such as fire reaction and sound insulation. Moreover, the PUF can efficiently improve the mechanical properties of the structure compared to the air gaps. Furthermore, in wet environments, the PUF plays a significant role in improving the susceptibility to fungi $[35,45,46]$. From above and to avoid the issues related to convection and radiation heat transfer in air cavities, in this paper, the lower thermal conductivity, weight, and cost PUF has been suggested to be the filler of the brick hollows in order to achieve the above properties within several applications. Here, a PUF with the common thermal conductivity of $0.022(\mathrm{~W} / \mathrm{m}-\mathrm{K})$ has been selected that has been exhibited in the environmental temperature ranges [44].

\section{Equivalent Thermal Properties Calculation}

Under the paper scope conditions for the brick and wall model, the heat diffusion equation is the general governing equation as shown below

$$
\frac{\partial^{2} T}{\partial x^{2}}+\frac{\partial^{2} T}{\partial y^{2}}+\frac{\partial^{2} T}{\partial z^{2}}+\frac{\dot{q}}{K}=\frac{1}{\alpha} \frac{\partial T}{\partial t}
$$

For simplicity, the dynamic heat transfer model has been assumed at two-dimensional (2D) steady-state transfer as the third dimension of the geometry is identical that that leads to the energy storage amount has no change $\left(\frac{\partial \mathrm{T}}{\partial \mathrm{t}}=0\right)$, and with no heat generation inside the model $(\dot{q}=0)$. In addition, due to the high amounts and thicknesses of the wall components compared to their contact surfaces, the thermal contact resistances have been neglected. The study focused on the heat transfer effect though the thickness thus the governing equation has been represented in the Z-direction only and from all the above, it has been reduced to

$$
\frac{d}{d z}\left(K_{n} \cdot \frac{\partial T}{\partial z}\right)=0
$$


The boundary conditions are,

The left side $\mathrm{T}(\mathrm{Y}, \mathrm{Z})=\mathrm{T}(\mathrm{Y}, 0)=\mathrm{T}_{\text {hot }}$
The right side $\mathrm{T}(\mathrm{Y}, \mathrm{Z})=\mathrm{T}(\mathrm{Y}, \mathrm{W})=\mathrm{T}_{\text {cold }}$

The upper surface $\mathrm{T}(\mathrm{Y}, \mathrm{Z})=\mathrm{T}(0, \mathrm{Z}) \rightarrow \frac{\partial \mathrm{T}}{\partial \mathrm{z}}=0$

The lower surface $T(Y, Z)=T(L, Z) \rightarrow \frac{\partial T}{\partial z}=0$

Therefore, the thermal conductivity of any geometry can be found theoretically by Fourier's law [47]

$$
\begin{gathered}
q=-K_{n} \cdot \frac{\Delta T}{\Delta n} \\
K_{n}=-q \cdot \frac{\Delta n}{\Delta T}
\end{gathered}
$$

where, $\mathrm{q}, K_{n}$ or $K, \Delta T, \Delta n$ are the heat flux $\left(\mathrm{W} / \mathrm{m}^{2}\right)$, thermal conductivity $(\mathrm{W} / \mathrm{m}-\mathrm{K})$, surface temperature gradient $\left(T_{\text {hot }}-T_{\text {cold }}\right)$, and the distance between the two surfaces in n-direction (m), respectively. Here, $T_{\text {hot }}$ and $T_{\text {cold }}$ have been arbitrarily chosen as 100 and $0^{\circ} \mathrm{C}$.

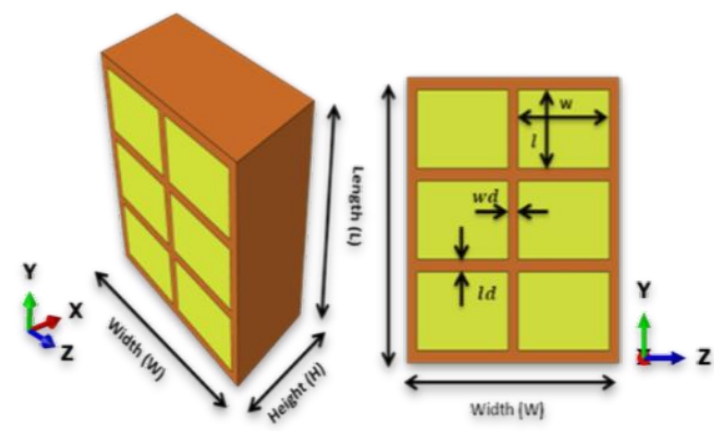

Figure 2. Hollow brick pattern of three rows (m) and two columns (n)

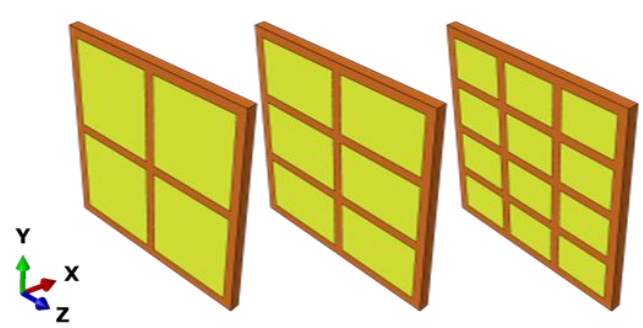

b)

c)

Figure 1. The hollow brick models with a) $2 \times 2$, b) $3 \times 2$, and c) $4 \times 3$ cavities.

Figure 2 shows three types of hollow brick models in the way of rows and columns $(m x n)$, and Figure 1 explains the dimensional details of $3 \times 2$ hollow brick. During this study, in seek of time investment, simplified and fast calculations, and reduction of modeling costs, a few shapes of theoretical thermal equations have been derived to calculate equivalent thermal conductivity of a brick $\left(K e q v_{b r}, \mathrm{~W} / \mathrm{m}-\mathrm{K}\right)$ in the $\mathrm{x}$-direction, and of a wall along the thickness direction $\left(K e q v_{\text {thickness }}, \mathrm{W} / \mathrm{m}-\mathrm{K}\right)$ regardless of the other thermal conditions of the geometry. Those equations (9), (10) and (12) are based only on the dimensions and thermal conductivities of the geometry's components.

$$
q_{\text {brick } / \text { mortar }}=-\frac{\Delta T}{\text { thickness }} \times K_{b r / \text { mortar }}
$$




$$
\begin{gathered}
q_{\text {cavity }}=-\frac{\Delta T}{\text { thickness }} \times K_{\text {cavity }} \\
q_{\text {total }}=-\frac{\Delta T}{\text { thickness }} x \text { Keqv } \\
q_{\text {eqv-brick }}=q_{\text {brick }} x(\% \text { or } \% A)_{\text {brick material }}+q_{\text {cavity }} x(\% \text { or } \% A)_{\text {cavity }}
\end{gathered}
$$

Thus,

$$
\begin{gathered}
K e q v_{b r}=K_{b r} x(\% \text { or } \% A)_{\text {brick material }}+K_{\text {cavity }} x(\% \text { or } \% A)_{\text {cavity }} \\
K e q v_{b r}=\frac{\text { w.l.m.n }}{W \cdot L} x\left[K_{f}+K_{b r} x\left(\frac{W \cdot L}{\text { w.l.m.n }}-1\right)\right] \\
q_{\text {walltotal }}=q_{\text {eqv-brick }} x(\% \text { or } \% A)_{\text {eqv-brick }}+q_{\text {mortar }} x(\% \text { or } \% A)_{\text {mortar }} \\
\text { Keqv } v_{\text {thickness }}=K e q v_{b r} x(\% \text { or } \% A)_{\text {brick }}+K_{\text {mortar }} x(\% \text { or } \% A)_{\text {mortar }}
\end{gathered}
$$

where, $\% V$ and $\% A$ of a component is the volume fraction and the fraction of the cross-sectional area perpendicular to the heat direction of the component to the total brick, respectively. The $w$ and $l$ are the width and height of the cavity, $W$ and $L$ are the width and length of the brick, and $K_{\text {brick/mortar }}$ and $K_{f}$ are the thermal conductivities of brick or mortar, and the filling material of a cavity, e.g. air, foams, or so on, respectively, where subscript $(f)$ is referred to as the type of the filler insulation material. Eqs.(9) and (10) are used for the filled and non-filled hollow bricks or blocks.

Eq.(9) can be used for all hollow bricks/blocks; however, in case of the uniform cavities repeated within the brick in the way of $m \times n$, the Eq.(10) can be effectively used for the thermal conductivity calculation. The Eq.(12) can be directly used to find the thermal conductivity of the wall-based only on the thermal conductivity and dimensions of bricks, mortars and any structural component. The $q_{\text {eqv-brick }}$ is the heat flux $\left(\mathrm{W} / \mathrm{m}^{2}\right)$ transferred through the homogenous solid brick that has the thermal properties of the corresponding hollow brick. In respect of the transferred heat flux through the wall $\left(q_{\text {wall total }}\right)$, the Eq.(11) based on the $q_{\text {eqv-brick }}$ and the heat flux through the mortar $\left(q_{\text {mortar }}\right)$.

The limitation of the paper's equations is that the equations are not applicable for non-uniform sections, e.g., the brick of Alghamdi and Alharthi [10] in case of y- and z-directions as shown in Figure 1. However, in such cases, the thermal conductivity and resistance can be found by the standard heat transfer calculations and modeling approaches.

In general, for thermal analysis, there are many experimental and theoretical approaches, and software packages have been used $[11,19,28,48,49]$. However, in this study, the finite element method (FEM) has been adopted by using ABAQUS software [50], which has proved its ability to model and simulate bricks under different configurations and conditions [10,51]. It has been also used to calculate the sum total of heat flux of the inner surface nodes to find the average heat flux $\left(q_{\text {total }}\right)$. Consequently, the Eq.(9) can be easily used to find the equivalent thermal conductivity $\left(K e q v_{b r}, \mathrm{~W} / \mathrm{m}-\mathrm{K}\right)$. With regards to the overall thermal resistance (Reqvithickness, $\mathrm{m}^{2}-\mathrm{k} / \mathrm{W}$ ), it can be simply calculated by applying the Fourier's law, based on the brick/wall equivalent thermal conductivity and their thickness as shown in Eq.(13),

$$
R e q v_{\text {thickness }}=\frac{\text { brick or } \text { wall thickness }}{K e q v_{\text {thickness }}}
$$


For other properties such as the density, $\rho_{\text {eqv }}\left(\mathrm{kg} / \mathrm{m}^{3}\right)$, the volumetric heat capacity, $\left(C_{p} . \rho\right)_{\text {eqv }}\left(\mathrm{kJ} / \mathrm{m}^{3} . \mathrm{K}\right)$, and equivalent thermal diffusivity, $\alpha_{e q v}\left(\mathrm{~m}^{2} / \mathrm{s}\right)$. In order to continue with the study that mainly based on simple and applicable equations, and to avoid any numerical or FE modeling, Habib, Cianfrini and De Lieto Vollaro study [12] have suggested the formulas below to obtain those thermal properties. The approach of those researchers is more simple and proper than other approaches as explained in detail in Arendt et al. [31].

$$
\begin{gathered}
\rho_{e q v}=\rho_{b r} x(\% V \text { or } \% A)_{\text {bricks }}+\rho_{f} x(\% V \text { or } \% A)_{\text {cavity }} \\
\left(C_{p} \cdot \rho\right)_{e q v}=\left(C p_{b r} \cdot \rho_{b r}\right) x(\% V \text { or } \% A)_{\text {bricks }}+\left(C p_{f} \cdot \rho_{f}\right) x(\% \text { or } \% A)_{\text {cavity }} \\
\alpha_{e q v}=\frac{K e q v_{\text {thickness }}}{\left(C_{p} \cdot \rho\right) \text { eqv }}
\end{gathered}
$$

Table 2. Component properties of the hollow brick wall

\begin{tabular}{|c|c|}
\hline Phase & Thermal Conductivity (W/m-K) \\
\hline Fired red clay & 1.400 \\
\hline Insulation mortar & 0.200 \\
\hline Air & 0.026 \\
\hline
\end{tabular}

\section{Brick Model}

Three dimensions finite-element (FE) model of $400 \times 200 \times 200 \mathrm{~mm}$ hollow brick is adopted. These dimensions are the common brick dimensions in building constructions $[2,10]$. The red clay has been selected to be the brick material due to its desired thermal properties in front of other masonry materials such as the concrete material as explained in the review. The brick material and air cavities have been assigned the thermal properties as mentioned previously in Table 2. In the present study, the brick design consists of five geometric holes, four of which are identical uniform thin geometries are distributed at each corner, and a $50 \mathrm{x} 100 \mathrm{~mm}$ central rectangular hole as shown in Figure 4. In the x-direction, the cross-sectional design is uniform, and the masonry partitions thickness is $9.2 \mathrm{~mm}$ in length $(l d)$ and $8.8 \mathrm{~mm}$ in height $(w d)$, which yields the model to be $0.71 \%$ cavity and $0.29 \%$ fired red clay. The $l d$ and $w d$ have been selected at a lower value to reduce the volume fraction of the masonry material, but they remain in the allowable dimensions of the brick standards. The minimum thicknesses exhibit effective strength and thermal properties, as proved in Arendt et al. [31], Al-Hadhrami and Ahmad [2], and

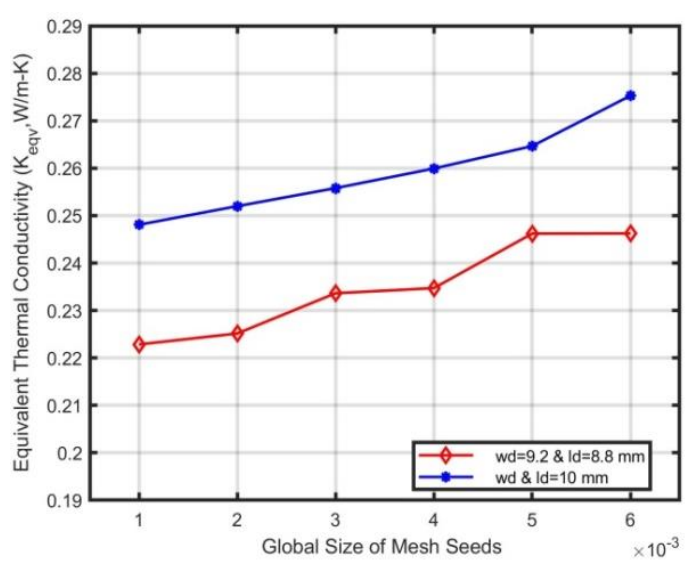

Figure 3. Effect of global size seeds of the FE mesh on equivalent thermal conductivity

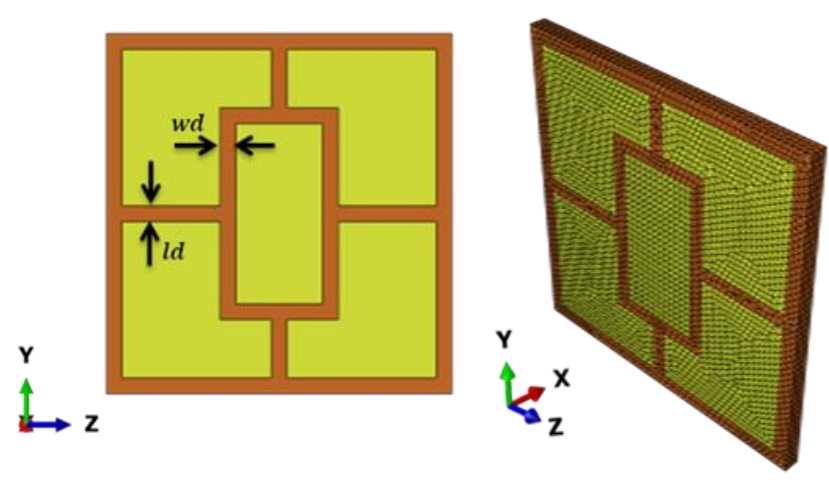

Figure 4. Cross-sectional and Finite-element model of hollow brick of the study 
Alghamdi and Alharthi [10] studies. As shown in Eq.(4), the thermal conductivity depends only on the heat flux, surface temperature gradient, and the distance between the outer and inner surfaces. However, in the FE analysis (FEA), Figure 3 shows that there has been an effect of mesh seeds (element size) on the equivalent thermal conductivity of the brick in the z-direction that resulted from the brick components (masonry material and cavity) have been arranged in the series way (isothermal surfaces) that makes a surface to surface interaction between them. For computational time reduction, the FE mesh has been with an approximate global seeds size of .004, 52456 linear tetrahedral elements of type DC3D4, which is basic and specific for heat transfer analysis and satisfied the paper scope has a 4-node linear tetrahedron shape (the lowest nodes), in addition, only $10 \mathrm{~mm}$ thickness has been modeled.

\section{Wall Unit Cell}

The paper approach and equations are applicable for all walls had a homogenous cross-sectional area regardless of the construction. However, the wall unit cell has been constructed in the multiscale model as in Alghamdi and Alharthi study [10] that have been explained in the introduction, Figure 5. The two-phase wall consisted of brick and insulation mortar. The little change in mortar thickness has no significant effect on thermal insulation as the volume fraction is much less than the bricks in the wall, thus it has been arbitrarily set at $10 \mathrm{~mm}$. The hollow brick has the dimensions of 400x200x200 mm, but, it has been modeled as a solid brick with the properties that gained from the brick model to be a wall has a cross-sectional area of $240 \times 240 \mathrm{~mm}$ and consist of (93\%) red clay brick and (7\%) insulation mortar. In contrast to Alghamdi and Alharthi and other 3D and 2D modeling studies, and for computational cost and time reduction, addition to that the third dimension of the wall unit cell has been identical, thus in this paper, only a simplified 2D model has been considered that resulted from the effective role of the Eqs.(8) and (12). These equations can be directly calculated the required thermal properties without the need for any 3D numerical or FE simulation or their challenges.

\section{Model Validation}

The conduction heat transferred through a matter is calculated by using Fourier's law in different approaches such as 2D and 3D numerical/finite element, finite-difference, or energy balance methods [47]. However, the paper's equations can easily employ this law in the multiscale 2D simple approach explained in section 2.4. In order of the validity of the equations, the equations have been applied in Alghamdi and Alharthi study. For this part, the FE model has been implemented by the ABAQUS software for validation purpose only, the wall unit cell has been modeled with only $10 \mathrm{~mm}$ at FE mesh have seeds of approximate global size. 0.02 and 2935 linear tetrahedral elements of type DC3D4. Therefore, with regard to the FE mesh, when finding the thermal properties in the $\mathrm{x}$-direction of the hollow brick, and in the z-direction of the wall, Figure 5, there is no need to model the brick or the wall with a fine mesh. This resulting from that the components of the brick and the wall (bricks and mortar) have been arranged in the parallel way (adiabatic surfaces) that makes no surface to surface interaction between them. Thus the thermal conductivity and resistance of each component are dependent, which consequently, the mesh size has no effect. Alghamdi and Alharthi [10] presented their study outcomes as a table, thus in this paper, the authors have validated the work that related to the scope and they have shown the results in the way of table. The validation results have summarized in Table 3 as shown below, where the results of the theoretical equations and simulated model of this paper reveal an excellent agreement with the outcomes of Alghamdi and Alharthi [10]. However, the outcomes are limited to bricks/blocks that have a uniform crosssectional area along the heat transfer direction.

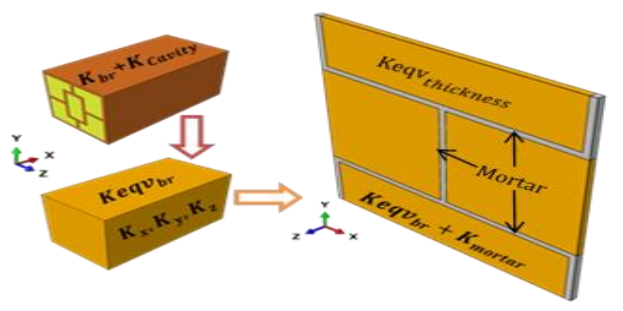

Figure 5. Modelling of the equivalent thermal conductivity of the wall 
Table 3. Validation of the Study Equivalent Thermal Conductivities

\begin{tabular}{|c|c|c|c|c|c|c|}
\hline \multirow{3}{*}{$\begin{array}{l}\text { The } \\
\text { control } \\
\text { volume }\end{array}$} & \multirow{3}{*}{\multicolumn{2}{|c|}{$\begin{array}{l}\text { The volume fraction } \\
\%\end{array}$}} & \multicolumn{4}{|c|}{$\begin{array}{l}\text { Equivalent Thermal Conductivity }(\mathrm{W} / \mathrm{m}-\mathrm{K}) \\
K e q v_{\text {thickness }}, \text { for the wall, } K e q v_{X}, \text { for the brick }\end{array}$} \\
\hline & & & \multicolumn{2}{|c|}{$[10]$ study } & \multicolumn{2}{|c|}{ This study } \\
\hline & & & Simulation & Experimental & Simulation & Theoretical \\
\hline \multirow{2}{*}{$\begin{array}{l}\text { The hollow } \\
\text { brick }\end{array}$} & $\begin{array}{l}\text { Fired } \\
\text { red clay }\end{array}$ & Air & \multirow[t]{2}{*}{0.52} & \multirow[t]{2}{*}{ - } & \multirow[t]{2}{*}{0.52} & \multirow[t]{2}{*}{0.52} \\
\hline & $36.2 \%$ & $63.8 \%$ & & & & \\
\hline \multirow{3}{*}{$\begin{array}{l}\text { The wall } \\
\text { of hollow } \\
\text { bricks }\end{array}$} & $\begin{array}{l}\text { Brick } \\
\text { model }\end{array}$ & Mortar & & & & \\
\hline & \multirow[t]{2}{*}{$93 \%$} & $\begin{array}{c}\text { Non- } \\
\text { insulation } \\
\text { Mortar } 7 \%\end{array}$ & 0.43 & - & 0.429 & 0.429 \\
\hline & & $\begin{array}{l}\text { Insulation } \\
\text { Mortar } 7 \%\end{array}$ & 0.304 & 0.495 & 0.347 & 0.347 \\
\hline
\end{tabular}

\section{RESULTS AND DISCUSSION}

The conduction heat transfer is the energy transport in a medium because of a temperature gradient, and the molecular activity or random atomic is the physical mechanism of this type of heat transfer that governed by Fourier's law as mentioned in section 2.2 [47]. The heat transfer in the hollow-brick walls consists of two mechanisms, firstly it is the conduction that represented by the brick and secondly, it is the convection that represented by heat transfer inside the cavities. For porous media (PUF), the heat transfer also involves conduction in the porous material (solid particles) and convection inside the voids. Therefore, the brick and the wall can be assumed as one matter with thermal equivalent properties. The gradient temperature form the hot to the cold surface is similar in the behavior of the solid bodies, but it is dealt with by the equivalent thermal properties.

In applications required foam cavity, for the paper brick design, the study's outcomes of filling the air cavity $(0.026 \mathrm{~W} / \mathrm{m}-\mathrm{K})$ by PUF $(0.022 \mathrm{~W} / \mathrm{m}-\mathrm{K})$ have revealed theoretically and also in simulation; the brick has shared the more effective and significant thermal properties of the air-cavity brick. In contrary to actual PUF noticeable activation in a reduction in the transferred heat flux and also the equivalent thermal conductivity and thus enhance the thermal insulation, it has shown no significant improvement for the overall thermal properties. This issue could result from the neglected effects of the convection and radiation heat transfers inside the brick

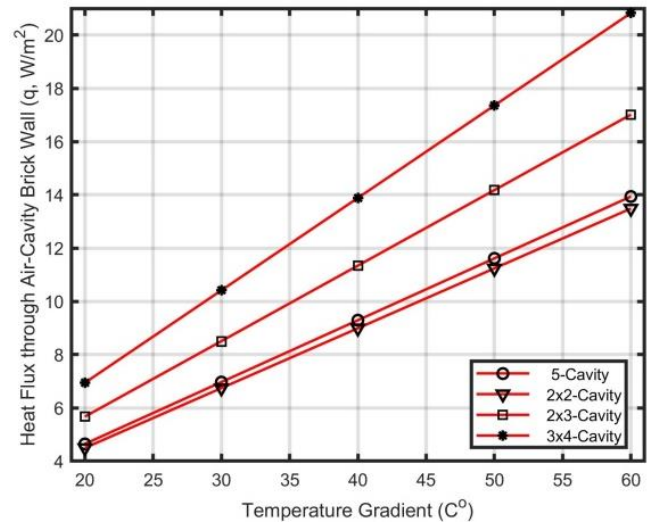

Figure 6. Effect of temperature gradient on the transferred heat flux, with PUF cavity

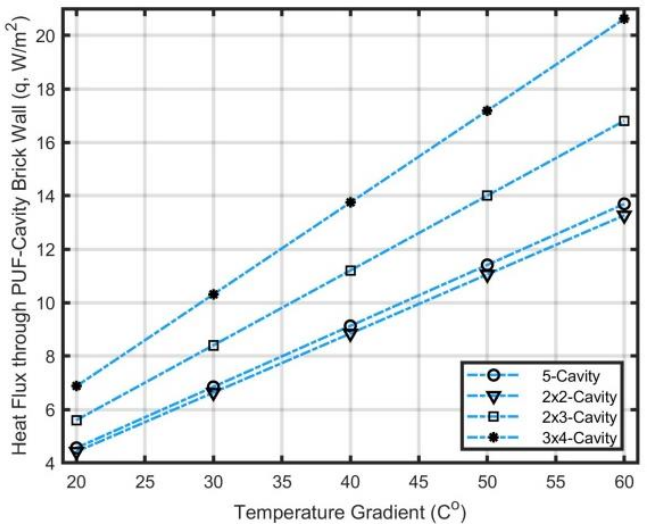

Figure 7. Effect of temperature gradient on the transferred heat flux, with Air cavity

air-cavities, for simplicity, which leads to showing the results of thermal insulation properties of both cavity materials at the same values approximately. However, in practice, the PUF can significantly enhance the thermal resistance when compared to cavity-fillers with a thermal conductivity higher than $0.022 \mathrm{~W} / \mathrm{m}-\mathrm{K}$ as discussed in the literature review. Nevertheless, with those paper outcomes, the PUF could also add other required features such as the strengthening, environmental and sound insulation aspects, as mentioned before. 
Figure 6 and Figure 7 show the temperature gradient influence on the heat flux independent on the brick cavity. Previously, it has pointed out that the temperature difference between the inner and outer surfaces of the wall has been arbitrarily set at $100^{\circ} \mathrm{C}$. However, to assess the effect of the temperature gradient on the heat leak, Figure 6 and Figure 7 have clarified that the gradient directly affects the transferred heat flux through the wall thickness.

For the brief and summarizing purpose, therefore, most of the figures and graphs of the result have been applied on air cavities only as there is no significant difference in results compared to PUF as clarified in Figure 8. Basically, if it has been used a lower thermal conductivity foam, it would be developed better thermal insulation, but as mentioned before, this study has focused on the popular filler foam suitable for various applications.

In addition, Figure 8 clearly shows that the brick of this study (five cavities) and $2 \times 2$-cavity brick have the lowest thermal conductivity and heat transfer per the thickness of the brick and thus the constructed wall $(\mathrm{W} / \mathrm{m})$. However, the non-aligned air-cavity form has lower thermal conductivity than the aligned form and thus better thermal insulation. Besides, a $2 \times 2$-air cavity brick has a cavity with a higher $l$ and $w$ that could exhibit a noticeable convection and radiation heat transfer that may affect the thermal insulation. Furthermore, compared to the volume fraction of the cavity material, the 5-cavity brick has a higher amount of high strength material (red clay) of $13 \%$ than the $2 \times 2$-cavity brick that could ensure better mechanical properties than the latter brick. Therefore, the brick of five non-aligned cavities has been selected for this study due to its thermal insulation performance and strength.

Figure 9 and Figure 8 depict the effect of the filling material and brick configurations on the equivalent thermal resistance, conductivity, and the transferred heat flux for one unit cross-sectional area of the wall. They reveal that both of the 5-cavity red clay brick and its brick wall have exhibited an equivalent thermal conductivity of $0.23 \mathrm{~W} / \mathrm{m}-\mathrm{K}$ that is higher by $18 \%$ and $33 \%$ than the $3 \times 2-$ and $4 \times 3$-cavity brick and their constructed wall, respectively. As declared in Table 3 and shown in Figure 5, the volume fraction of the clay bricks have dominated the wall unit cell that results in the brick and the wall has approximately the same value of the thermal conductivity. Therefore, It is worthy to mention that the wall constructed from solid red clay brick would exhibit a thermal conductivity close to brick $1.4(\mathrm{~W} / \mathrm{m}-\mathrm{K})$ which is more than $400 \%$ of thermal conductivity of the hollow brick wall.

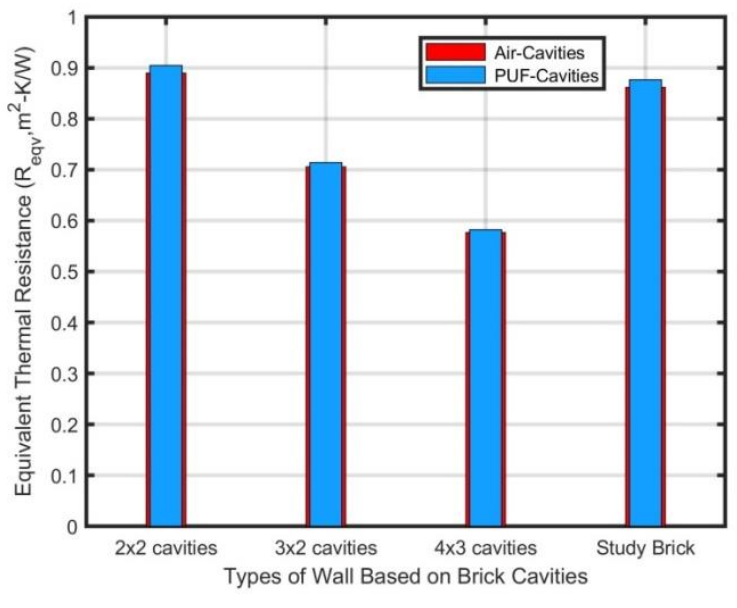

Figure 9. Effect of the filler material and cavity configurations on the equivalent thermal resistance

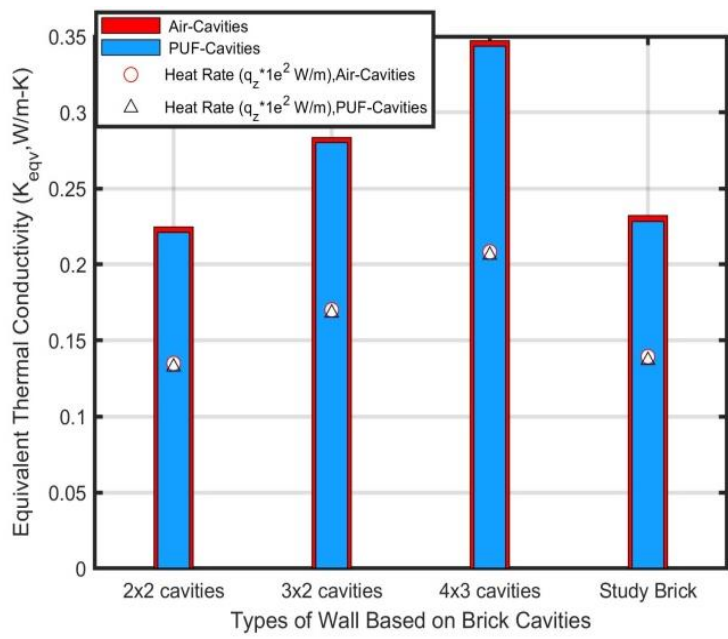

Figure 8. Effect of the filler material and cavity configurations on the thermal insulation

Figure 3 also shows the influence of the brick partitions ( $l d$ and $w d$ ) on the equivalent thermal conductivity in the brick z-direction. As shown in Eqs.(4), the thermal conductivity directly depends on the material thickness. Therefore, Figure 3 reveals that the slight increase in $(l d)$ and $(w d)$ has raised the equivalent thermal conductivity with about $11 \%$ due to the increase in the volume fraction of the high thermal conductivity material ahead of the lower conductivity cavity, and thus affects negatively the thermal insulation. 


\section{The Study Equations Application}

In the x-direction of this study brick, as shown in Figure 4, by using the Eq. (5) and (6), the $q_{\text {brick }}$ and $q_{\text {cavity }}$ has been 14000 and $260\left(\mathrm{~W} / \mathrm{m}^{2}\right)$, respectively. Those values have been used in Eq. (8) to obtain the throughthickness heat flux $\left(q_{\text {total }}\right)$, which have been $4215\left(\mathrm{~W} / \mathrm{m}^{2}\right)$. Based on the conductivity of red clay and filling material mentioned in Table 2, Eq.(9) can directly calculate the equivalent thermal conductivity of the brick $\left(K e q v_{b r}\right)$ that has been $0.42(\mathrm{~W} / \mathrm{m}-\mathrm{K})$. In the wall unit cell, the Eq. (5) and (8) can supply the $q_{\text {mortar }}$ and the $q_{\text {eqv-brick }}$, respectively, and consequently calculate the $q_{\text {wall total }}$ by the Eq.(11) as $2323\left(\mathrm{~W} / \mathrm{m}^{2}\right)$. Based on the $K e q v_{b r}$ from above and the $K_{\text {mortar }}$ from Table 2, the straight Eq.(12) can effectively calculate the equivalent thermal conductivity through the wall thickness (Keqvithickness) that has given for the wall constructed from aircavity and PUF-cavity bricks a 0.23 and $0.22(\mathrm{~W} / \mathrm{m}-\mathrm{K})$, respectively.

\section{The finite element modeling}

By using ABAQUS software, Figure 10 illustrates the temperature distribution (NT11, K) and heat flux (HFL, $\mathrm{W} / \mathrm{m}^{2}$ ) contours of the FE modeling of $10 \mathrm{~mm}$ brick thickness. The results have shown that the $q_{\text {eqv-brick }}$ in the $\mathrm{y}$ - and z-direction have been 127 and $117\left(\mathrm{~W} / \mathrm{m}^{2}\right)$, respectively, and the $K e q v_{b r}$ has been 0.25 and 0.24 $(\mathrm{W} / \mathrm{m}-\mathrm{K})$, respectively.

Figure 11 shows the transferred heat flux through the brick wall. The FEA has been used to obtain the $q_{\text {wall total }}$ for the validation aim only, which has been $2323\left(\mathrm{~W} / \mathrm{m}^{2}\right)$. The Keqvithickness has been $0.23(\mathrm{~W} / \mathrm{m}-\mathrm{K})$ exactly to the same value of that calculated by the Eq.(12).
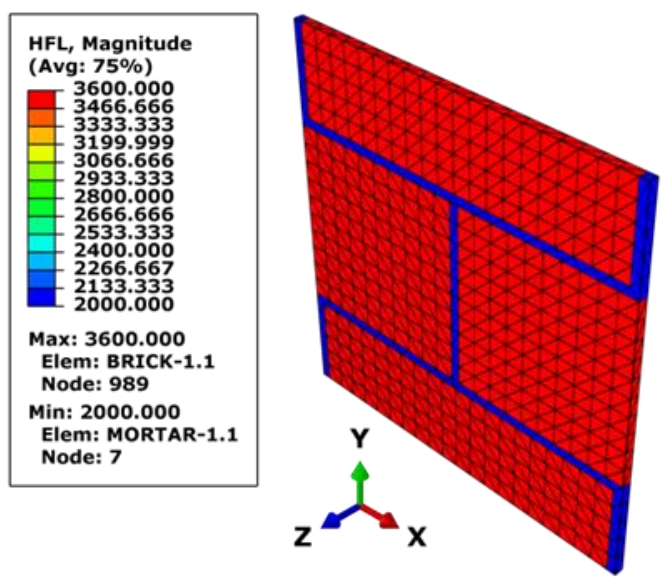

Figure 10. Contours of wall heat flux (HFL,W/ $\mathrm{m}^{2}$ ) by ABAQUS simulation.

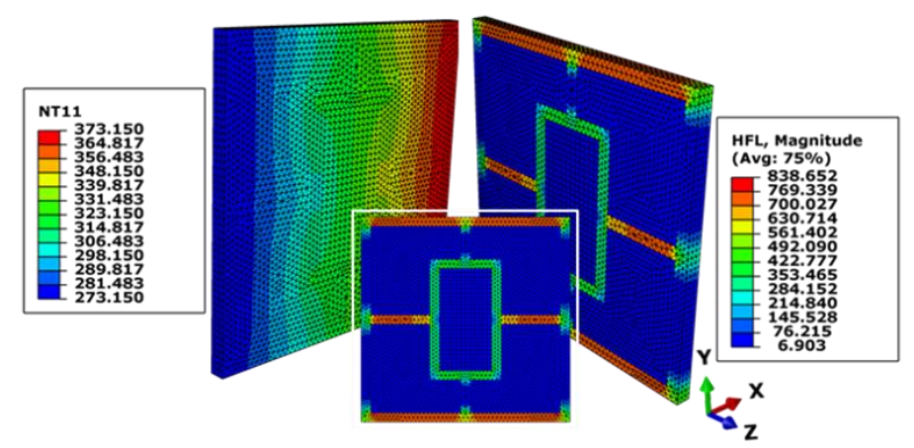

Figure 11. Contours of brick temperature distribution (NT11, K) and heat flux $\left(\mathrm{HFL}, \mathrm{W} / \mathrm{m}^{2}\right)$ by ABAQUS simulation.

There are several thermal aspects taken into consideration when comparing in the thermal performance, such as the reduction in the heat flux or thermal conductivity, or the increase in the thermal insulation. Nevertheless, according to the principles of the Fourier low, Eqs.(4) and (13), all the aspects mentioned above would exhibit the same description of the changes in thermal performance. Consequently, the results have focused on the paper's main thermal property, which is equivalent to thermal conductivity.

it can be clearly seen that the thermal Figure 12 depicts a comparison between the equivalent thermal conductivity of hollow bricks which were optimized in the literature works of Al-Hadhrami and Ahmad[2], Alghamdi and Alharthi[10], Li, Wu, Li, et al [9], and Sun and Fang [1] and the brick, which has been designed in the resent study. 


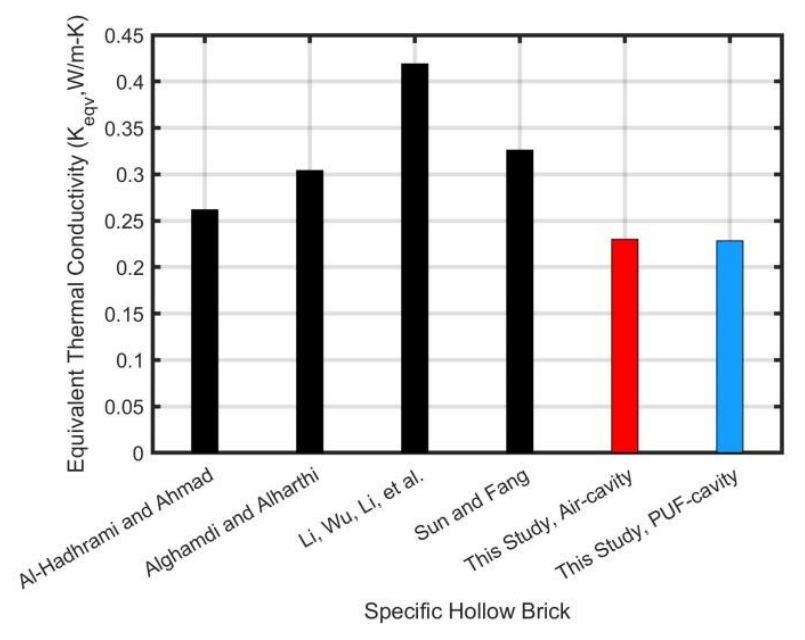

Figure 12. Thermal conductivity of the hollow bricks from different references

As seen the brick design of this paper has noticeably decreased the thermal conductivity and the transferred heat flux compared to the optimized hollow brick due to the optimum design of the cavities inside the study brick. The percent of the thermal insulation performance has been slightly higher than the design of AlHadhrami and Ahmad, and Alghamdi and Alharthi as $12 \%$ and $24 \%$, respectively. However, it has been significantly higher than the bricks of the rest studies as $30 \%$ and $45 \%$ to the designs of Sun and Fang, and $\mathrm{Li}$, Wu, $\mathrm{Li}$, et al., respectively.

\section{CONCLUSIONS}

For the purpose of keeping a single main wall with a high insulation performance and saving the cost and time of construction and computations. This study has optimized a hollow red clay brick and brick wall by using the multiscale method. Equations have been derived to calculate the thermal insulation properties in a simple way. Foam-filled and non-filled bricks have been examined. Different brick configurations and conditions have been thermally analyzed by using those effective equations and the finite element method. The equations' limitations are that they are applicable only for structures that had a uniform sectional area. The outcomes may be illustrated:

- $\quad$ Simple and useful equations have been derived and applied to a multiscale modeling technique that has predicted the equivalent thermal insulation, e.g., conductivity, resistance, and transferred heat flux for the bricks and brick walls fast, and accurately, and simply.

- In foam-cavity brick applications, when using low thermal conductivity filling foam such PUF, in the study scope, there has been no significant difference in the overall thermal properties, but, when considering the convection and radiation heat transfer inside the cavities, it could exhibit the obvious effectiveness and performance in the thermal insulation. Moreover, the PUF can enhance some additional characteristic properties such as sound insulation and anti-fungi, and mechanical properties to some extent.

- $\quad$ The thickness of hollow brick partitions ( $l d$ and $w d$ ) has a noticeable negative effect on the thermal insulation.

- $\quad$ The specific design of 5-cavity brick has revealed a significant thermal insulation performance that has shown $12-45 \%$ than the cavity-shape bricks of other corresponding research studies.

Future research studies should use various designs and configurations of hollow brick and wall. In addition, the study should cover the fully coupled thermo-mechanical analysis of the filled and non-filled hollow bricks and walls. Moreover, improve and modify the equations to be applied in the thermal analysis for several parts of building construction and compare results with other corresponding methods. 


\section{NOMENCLATURE}

Roman letters

$\% A$

$\% V$

$\left(C_{p} \rho\right)_{e q v}$

$K_{f}$

$K_{\text {brick/mortar }}$

$K e q v_{b r}$

$K e q v_{b r . x}$

Keqv thickness

$T_{\text {hot }}$

$T_{\text {cold }}$

$q_{\text {eqv-brick }}$

$q_{\text {mortar }}$

$q_{\text {total }}$

$q_{\text {wall total }}$

$\Delta T$

$\Delta n$

2D

3D

FE

FEA

PE

PS

PU

PUF

PUFs

PVC

$\mathrm{q}$

K

L

Reqv $v_{\text {thickness }}$

W

l

ld

m

$n$

$w$

wd

Greek symbols

$\alpha$

$\alpha_{e q v}$

$\rho_{\text {eqv }}$

Subscripts

$f$

n

br
Fraction of cross-sectional area

Volume fraction

Equivalent volumetric heat capacity, $\mathrm{kj} / \mathrm{m}^{3}-\mathrm{K}$

Thermal conductivities of filling material, $\mathrm{W} / \mathrm{m}-\mathrm{K}$

Thermal conductivities of brick or mortar, W/m-K

Equivalent thermal conductivity, W/m-K

Thermal conductivity of a brick in the $\mathrm{x}$-direction, $\mathrm{W} / \mathrm{m}-\mathrm{K}$

Thermal conductivity of a wall along thickness direction, $\mathrm{W} / \mathrm{m}-\mathrm{K}$

Temperature of the hot surface, $\mathrm{K}$

Temperature of the cold surface, $\mathrm{K}$

Heat flux through a homogenous solid brick, W/m $m^{2}$

Heat flux through mortar, $\mathrm{W} / \mathrm{m}^{2}$

Average heat flux, $\mathrm{W} / \mathrm{m}^{2}$

Heat flux through wall, $\mathrm{W} / \mathrm{m}^{2}$

Surface temperature gradient

Distance between the two surfaces in n-direction

Two-dimensional

Three-dimensional

Finite-element

Finite-element analysis

Polyethylene

Polystyrene

Polyurethane

Insulation polyurethane foam

Polyurethane foams

Polyvinyl chloride

Heat flux, W/m²

Thermal conductivity, W/m-K

Brick height, mm

Overall thermal resistance, $\mathrm{m}^{2}-\mathrm{k} / \mathrm{W}$

Brick width, mm

Cavity height, $\mathrm{mm}$

Masonry partition length, mm

Number of rows

Number of columns

Cavity width, mm

Masonry partition height, $\mathrm{mm}$

Thermal diffusivity, $\mathrm{m}^{2} / \mathrm{s}$

Equivalent thermal diffusivity, $\mathrm{m}^{2} / \mathrm{s}$

Equivalent density, $\mathrm{kg} / \mathrm{m}^{3}$

Filler insulation material

n-direction

Brick 


\section{REFERENCES}

[1] Sun J, Fang L. Numerical simulation of concrete hollow bricks by the finite volume method. Int J Heat Mass Transf 2009;52:5598-607. https://doi.org/10.1016/j.ijheatmasstransfer.2009.06.008.

[2] Al-Hadhrami LM, Ahmad A. Assessment of thermal performance of different types of masonry bricks used in Saudi Arabia. Appl Therm Eng 2009;29:1123-30. https://doi.org/10.1016/j.applthermaleng.2008.06.003.

[3] Mohsen MS, Akash BA. Some prospects of energy savings in buildings. Energy Convers Manag 2001. https://doi.org/10.1016/S0196-8904(00)00140-0.

[4] Sadineni SB, Madala S, Boehm RF. Passive building energy savings: A review of building envelope components. Renew Sustain Energy Rev 2011;15:3617-31. https://doi.org/10.1016/j.rser.2011.07.014.

[5] Zhang L, Luo T, Meng X, Wang Y, Hou C, Long E. Effect of the thermal insulation layer location on wall dynamic thermal response rate under the air-conditioning intermittent operation. Case Stud Therm Eng 2017;10:79-85. https://doi.org/10.1016/j.csite.2017.04.001.

[6] Du J, Chan M, Pan D, Shang L, Deng S. The impacts of daytime external envelope heat gain/storage on the nighttime cooling load and the related mitigation measures in a bedroom in the subtropics. Energy Build 2016;118:70-81. https://doi.org/10.1016/j.enbuild.2016.02.010.

[7] Lee S-T, Ramesh NS. Polymeric foams: mechanisms and materials. CRC Press; 2004.

[8] Li LP, Wu ZG, He YL, Lauriat G, Tao WQ. Optimization of the configuration of $290 \times 140 \times 90$ hollow clay bricks with 3-D numerical simulation by finite volume method. Energy Build 2008;40:1790-8. https://doi.org/10.1016/j.enbuild.2008.03.010.

[9] Li LP, Wu ZG, Li ZY, He YL, Tao WQ. Numerical thermal optimization of the configuration of multiholed clay bricks used for constructing building walls by the finite volume method. Int J Heat Mass Transf 2008;51:3669-82. https://doi.org/10.1016/j.ijheatmasstransfer.2007.06.008.

[10] Alghamdi AA, Alharthi HA. Multiscale 3D finite-element modelling of the thermal conductivity of clay brick walls. Constr Build Mater 2017;157:1-9. https://doi.org/10.1016/j.conbuildmat.2017.09.081.

[11] Sun J, Fang L, Han J. Optimization of concrete hollow brick using hybrid genetic algorithm combining with artificial neural networks. Int J Heat Mass Transf 2010;53:5509-18. https://doi.org/10.1016/j.ijheatmasstransfer.2010.07.006.

[12] Habib E, Cianfrini M, De Lieto Vollaro R. Definition of Parameters Useful to Describe Dynamic Thermal Behavior of Hollow Bricks $\quad$ Energy Procedia 2017;126:50-7. https://doi.org/10.1016/j.egypro.2017.08.056.

[13] Yu J, Huang J, Xu X, Ye H, Xiong C, Wang J, et al. A semi-dynamic heat transfer model of hollow block ventilated wall for thermal performance prediction. Energy Build 2017;134:285-94. https://doi.org/10.1016/j.enbuild.2016.11.001.

[14] Yu J, Yang J, Xiong C. Study of dynamic thermal performance of hollow block ventilated wall. Renew Energy 2015;84:145-51. https://doi.org/10.1016/j.renene.2015.07.020.

[15] Xiong C, Yu J, Yang J. Study of the Simplified Dynamic Thermal Network Model for the Hollow Block Ventilated Wall. Procedia Eng 2015;121:1304-11. https://doi.org/10.1016/j.proeng.2015.09.008.

[16] del Coz Díaz JJ, García Nieto PJ, Betegón Biempica C, Prendes Gero MB. Analysis and optimization of the heat-insulating light concrete hollow brick walls design by the finite element method. Appl Therm Eng 2007;27:1445-56. https://doi.org/10.1016/j.applthermaleng.2006.10.010.

[17] del Coz Díaz JJ, García Nieto PJ, Suárez Sierra JL, Peñuelas Sánchez I. Non-linear thermal optimization and design improvement of a new internal light concrete multi-holed brick walls by FEM. Appl Therm Eng 2008. https://doi.org/10.1016/j.applthermaleng.2007.06.023.

[18] Del Coz Diaz JJ, Garcia-Nieto PJ, Alvarez-Rabanall FP, Alonso-Martínez M, Dominguez-Hernandez J, Perez-Bella JM. The use of response surface methodology to improve the thermal transmittance of lightweight concrete hollow bricks by FEM. Constr Build Mater 2014;52:331-44. https://doi.org/10.1016/j.conbuildmat.2013.11.056.

[19] Li J, Meng X, Gao Y, Mao W, Luo T, Zhang L. Effect of the insulation materials filling on the thermal performance of sintered hollow bricks. Case Stud Therm Eng 2018;11:62-70. https://doi.org/10.1016/j.csite.2017.12.007.

[20] Antoniadis KD, Assael MJ, Tsiglifisi CA, Mylona SK. Improving the design of greek hollow clay bricks. Int J Thermophys 2012;33:2274-90. https://doi.org/10.1007/s10765-012-1294-x.

[21] Al-Hazmy MM. Analysis of coupled natural convection-conduction effects on the heat transport through hollow building blocks. Energy Build 2006;38:515-21. https://doi.org/10.1016/j.enbuild.2005.08.010.

[22] Bouchair A. Steady state theoretical model of fired clay hollow bricks for enhanced external wall thermal insulation. Build Environ 2008;43:1603-18. https://doi.org/10.1016/j.buildenv.2007.10.005.

[23] Ling H, Wang L, Chen C, Chen H. Numerical investigations of optimal phase change material incorporated into ventilated walls. Energy 2019. https://doi.org/10.1016/j.energy.2019.01.066. 
[24] Ghalandari M, Mirzadeh Koohshahi E, Mohamadian F, Shamshirband S, Chau KW. Numerical simulation of nanofluid flow inside a root canal. Eng Appl Comput Fluid Mech 2019. https://doi.org/10.1080/19942060.2019.1578696.

[25] Ahmadi MH, Mohseni-Gharyehsafa B, Farzaneh-Gord M, Jilte RD, Kumar R, Chau K wing. Applicability of connectionist methods to predict dynamic viscosity of silver/water nanofluid by using ANN-MLP, MARS and MPR algorithms. Eng Appl Comput Fluid Mech 2019. https://doi.org/10.1080/19942060.2019.1571442.

[26] Baghban A, Jalali A, Shafiee M, Ahmadi MH, Chau K wing. Developing an ANFIS-based swarm concept model for estimating the relative viscosity of nanofluids. Eng Appl Comput Fluid Mech 2019. https://doi.org/10.1080/19942060.2018.1542345.

[27] Ramezanizadeh M, Alhuyi Nazari M, Ahmadi MH, Chau K wing. Experimental and numerical analysis of a nanofluidic thermosyphon heat exchanger. Eng Appl Comput Fluid Mech 2019. https://doi.org/10.1080/19942060.2018.1518272.

[28] Rasooli A, Itard L. In-situ characterization of walls' thermal resistance: An extension to the ISO 9869 standard method. Energy Build 2018. https://doi.org/10.1016/j.enbuild.2018.09.004.

[29] Coz Díaz JJ de., Nieto PJG, Sierra JLS, Biempica CB. Nonlinear thermal optimization of external light concrete multi-holed brick walls by the finite element method. Int J Heat Mass Transf 2008. https://doi.org/10.1016/j.ijheatmasstransfer.2007.07.029.

[30] Aouba L, Coutand M, Perrin B, Lemercier H. Predicting thermal performance of fired clay bricks lightened by adding organic matter: Improvement of brick geometry. J Build Phys 2015;38:531-47. https://doi.org/10.1177/1744259115571078.

[31] Arendt K, Krzaczek M, Florczuk J. Numerical analysis by FEM and analytical study of the dynamic thermal behavior of hollow bricks with different cavity concentration. Int J Therm Sci 2011;50:1543-53. https://doi.org/10.1016/j.ijthermalsci.2011.02.027.

[32] Wang F, Wang D, Wang X, Yao J. A data analysis method for detecting wall thermal resistance considering wind velocity in situ. Energy Build 2010;42:1647-53. https://doi.org/10.1016/j.enbuild.2010.04.007.

[33] Eaves D. Handbook of polymer foams. UK: Rapra Technology Ltd.; 2004. https://doi.org/10.5860/choice.42-0962.

[34] Ionescu M. Chemistry and technology of polyols for polyurethanes. . 2007. https://doi.org/10.1002/pi.2159.

[35] Gama N V., Ferreira A, Barros-Timmons A. Polyurethane foams: Past, present, and future. Materials (Basel) 2018;11. https://doi.org/10.3390/ma11101841.

[36] Jelle BP. Traditional, state-of-the-art and future thermal building insulation materials and solutions Properties, requirements and possibilities. Energy 2011. https://doi.org/10.1016/j.enbuild.2011.05.015.

[37] Carriço CS, Fraga T, Carvalho VE, Pasa VMD. Polyurethane foams for thermal insulation uses produced from castor oil and crude glycerol biopolyols. Molecules 2017;22. https://doi.org/10.3390/molecules22071091.

[38] Wang M, Pan N. Modeling and prediction of the effective thermal conductivity of random open-cell porous foams. Int J Heat Mass Transf 2008;51:1325-31. https://doi.org/10.1016/j.ijheatmasstransfer.2007.11.031.

[39] Fang W, Tang Y, Zhang H, Tao W. Numerical predictions of the effective thermal conductivity of the rigid polyurethane foam. J Wuhan Univ Technol Mater Sci Ed 2017;32:703-8. https://doi.org/10.1007/s11595017-1655-1.

[40] Kirpluks M, Kalnbunde D, Benes H, Cabulis U. Natural oil based highly functional polyols as feedstock for rigid polyurethane foam thermal insulation. Ind Crops Prod 2018;122:627-36. https://doi.org/10.1016/j.indcrop.2018.06.040.

[41] Choi SW, Jung JM, Yoo HM, Kim SH, Lee W Il. Analysis of thermal properties and heat transfer mechanisms for polyurethane foams blown with water. J Therm Anal Calorim 2018;132:1253-62. https://doi.org/10.1007/s10973-018-6990-8.

[42] Demharter A. Polyurethane rigid foam, a proven thermal insulating material for applications between $+130^{\circ} \mathrm{C}$ and $-196^{\circ} \mathrm{C}$. Cryogenics (Guildf) 1998;38:113-117. https://doi.org/10.1016/S00112275(97)00120-3.

[43] Druma AM, Alam MK, Druma C. Analysis of thermal conduction in carbon foams. Int J Therm Sci 2004;43:689-95. https://doi.org/10.1016/j.ijthermalsci.2003.12.004.

[44] Gama NV, Amaral C, Silva T, Vicente R, Coutinho JAP, Barros-Timmons A, et al. Thermal energy storage and mechanical performance of crude glycerol polyurethane composite foams containing phase change materials and expandable graphite. Materials (Basel) 2018. https://doi.org/10.3390/ma11101896.

[45] Zhang L, Zhang M, Hu L, Zhou Y. Synthesis of rigid polyurethane foams with castor oil-based flame retardant polyols. Ind Crops Prod 2014. https://doi.org/10.1016/j.indcrop.2013.10.043. 
Journal of Thermal Engineering, Research Article, Vol. 7, No. 1, pp. 190-203, January, 2021

[46] Kausar A. Polyurethane Composite Foams in High-Performance Applications: A Review. Polym - Plast Technol Eng 2018. https://doi.org/10.1080/03602559.2017.1329433.

[47] Incropera FP, DeWitt DP, Bergman TL, Lavine AS. Fundamentals of Heat and Mass Transfer 6th Edition. 2011. https://doi.org/10.1016/j.applthermaleng.2011.03.022.

[48] Baghban A, Sasanipour J, Pourfayaz F, Ahmadi MH, Kasaeian A, Chamkha AJ, et al. Towards experimental and modeling study of heat transfer performance of water- $\mathrm{SiO} 2$ nanofluid in quadrangular cross-section channels. Eng Appl Comput Fluid 2019. https://doi.org/10.1080/19942060.2019.1599428.

[49] Ahmadi MH, Ghahremannezhad A, Chau K-W, Seifaddini P, Ramezannezhad M, Ghasempour R. Development of Simple-to-Use Predictive Models to Determine Thermal Properties of Fe2O3/WaterEthylene Glycol Nanofluid. Eng Appl Comput Fluid Mech 2019. https://doi.org/10.3390/computation7010018.

[50] Dassault Systemes Simulia Corp. Abaqus 6.14. 2017.

[51] Hashim A, Kyaw S, Sun W. Modelling fracture of aged graphite bricks under radiation and temperature. Nucl Mater Energy 2017;11:3-11. https://doi.org/10.1016/j.nme.2017.03.038. 